\title{
Conservation and Genetic Improvement of Gir Cattle
}

\author{
Vikramjit Singh ${ }^{1 *}$ and Poonam Choudhary ${ }^{2}$ \\ ${ }^{1}$ Department of Livestock Production Management, College of Veterinary and Animal \\ Science, Bikaner, RAJUVAS, Rajasthan, India \\ ${ }^{2}$ Department of Veterinary Parasitology, CVAS, Bikaner, RAJUVAS, Rajasthan, India \\ *Corresponding Author: Vikramjit Singh, Department of Livestock Production \\ Management, College of Veterinary and Animal Science, Bikaner, RAJUVAS, Rajasthan, \\ India.
}

Livestock are the best insurance against the vagaries of nature like drought, famine and other natural calamities. India's livestock sector is one of the largest in the world it has $56.7 \%$ of world's buffaloes, $12.5 \%$ cattle, $20.45 \%$ small ruminants, $2.4 \%$ camel, $1.4 \%$ equine, $1.5 \%$ pigs and $3.1 \%$ poultry (FAOSTAT, 2015 ). The total livestock population has decreased by about $3.33 \%$ over the previous census. There are fourty three (43) recognized breeds of cattle in India, in addition to large number of non-descript cattle (NBAGR, 2019). In recent times, several of the indigenous breeds suffered decline mainly due to their becoming uneconomical. Draught breeds utility has decreased because of mechanization in agriculture. The indigenous breeds have following merits over exotic breeds viz: Better disease resistance than exotic breeds, more suitable for low input management system, Survive better in local environment, Suitable for draught work and in addition to this existence of superior indigenous breeds can provide valuable research inputs for developing superior breeds. It is therefore important that Indigenous breeds of cattle are conserved, developed and proliferated. Cattle and buffalo genetic improvement will be done taking into consideration the farmers needs, market and agro climate and simultaneously conserving the livestock, biodiversity.

The main handicaps in the promotion of dairying along with the adverse climatic conditions are lack of green fodder, inadequate and unbalanced feeding, poor management, low genetic potential, inadequate veterinary aid and lack of market facilities. Efficient management is necessary to increase milk production. An efficient management needs a strong database. Efforts should be aimed to collect and correlate all available information. Few efforts are known to have been made to study systematically the cattle management practices in rural areas. The information available and the notation prevalent on the subject have been based on assumptions, usual observations, experience and reports of some specialists and professional workers. This is hardly adequate to serve as the basis on which valid guidelines for developing programs of introducing improved and scientific management practices and for solving the problems encountered. It is necessary to make systematic efforts and managemental practices by the Gir cattle keepers for Gir cattle conservational. The Indian Council of Agricultural Research (ICAR) started two projects on Gir cattle, one is executed by the National Bureau of Animal Genetic Resources (NBAGR) for the conservation of breed and another by the Project Directorate on Cattle (PDC) for genetic improvement. The objectives of the former project are to characterize the breed in terms of qualitative and quantitative traits, to study the molecular genetic characteristics of the breed, develop breed descriptors and conserve the germplasm of elite/ unique animals. The latter project aims to undertake testing and selection of bulls for the genetic improvement and to provide superior germplasm for utilisation in other development programmes. Even though the Rajasthan state is rich in the total animal population yet, the progress of animal husbandry does not seem to be satisfactory.

\section{Assets from publication with us}

- Prompt Acknowledgement after receiving the article

- Thorough Double blinded peer review

- Rapid Publication

- Issue of Publication Certificate

- High visibility of your Published work

Website: www.actascientific.com/

Submit Article: www.actascientific.com/submission.php Email us: editor@actascientific.com

Contact us: +919182824667 